DOI 10.31558/2307-2318.2018.4.7

УДК 336.71

Соколова Х.О., студентка 2 курсу магістратури, Донецький національний університет імені Василя Стуса

Волкова В.В., кандидат економічних наук, доцент, Донецький національний університет імені Василя Стуса

\title{
АКТИВИ ТА ПАСИВИ БАНКІВ УКРАЇНИ: СУЧАСНИЙ СТАН ТА ФАКТОРИ ВПЛИВУ
}

В статті доведено, що ефективне управління активами та пасивами є пріоритетним завданням будь-якого банку, оскільки від ефективності управління активами та пасивами залежить ліквідність банку, спроможність банку функціонувати під впливом різноманітних ризиків, його фінансова стійкість. За результатами дослідження уточнено визначення понять «активи банку» та «пасиви банку», дана оцінка стану активів та пасивів банків України за останні п'ять років; проаналізовано динаміку та склад активів та пасивів, динаміку та структуру наданих кредитів та залучених депозитів банків України. Виокремлено внутрішні та зовнішні фактори та визначено їх вплив на загальний розмір активів та пасивів банків; розроблено множинну регресійну модель впливу зовнішніх та внутрішніх факторів на загальну суму активів банків та множинну регресійну модель впливу складових активів та пасивів на їх розмір. Доведено, що моделі можна використовувати для подальшого аналізу та прогнозу. За допомогою статистичного пакету «Аналіз даних» Excel відібрано найбільш впливові фактори на загальну суму активів, побудовано економіко-математичну модель та визначено як саме відібрані чинники впливають на активи; за допомогою статистичної програми BP-stat зроблено прогноз суми активів на п'ять років з урахуванням відібраних факторів.

Ключові слова: активи, пасиви, управління активами та пасивами, фактори впливу.

\section{Соколова К.А., Волкова В.В.}

\section{АКТИВЫ И ПАССИВЫ БАНКОВ УКРАИНЫ: ТЕКУЩЕЕ СОСТОЯНИЕ И ФАКТОРЫ ВЛИЯНИЯ}

В статье доказано, что эффективное управление активами и пассивами является приоритетной задачей любого банка, поскольку от эффективности управления активами и пассивами зависит ликвидность банка, способность банка функционировать под влиянием различных рисков, его финансовая устойчивость. По результатам исследования уточнено определение понятий «активы банка» и «пассивы банка», дана оценка состояния активов и пассивов банков Украины за последние пять лет, проанализирована динамика и состав активов и пассивов, динамика и структура предоставленных кредитов и привлеченных депозитов банков Украины. Выделены внутренние и внешние факторы и определено их влияние на общий размер активов и пассивов банков; разработаны множественную регрессионную модель влияния внешних и внутренних факторов на общую сумму активов банков и множественную регрессионную модель влияния составляющих активов и пассивов на их размер. Доказано, что модели можно использовать для дальнейшего анализа и прогноза. С помощью статистического пакета «Анализ данных» Excel отобраны наиболее влиятельные факторы на общую сумму активов, построена экономико-математическая модель и определены как отобранные факторы влияют на активы; с помощью статистической программы BP-stat сделан прогноз суммы активов на пять лет с учетом отобранных факторов. 
Ключевые слова: активы, пассивы, управление активами и пассивами, факторы влияния.

\section{Sokolova Kh., Volkova V. \\ ASSETS AND LIABILITIES BANKS OF UKRAINE: CURRENT STATUS AND INFLUENCE FACTORS}

The article is proved that effective asset and liability management is a priority task of any bank. Because, the bank liquidity, the bank's ability to function under the influence of various risks, its financial stability depends on the efficiency asset and liability management. According to the results of the study, the definition of the concepts of "bank` assets" and "bank liabilities" has been specified. The assets and liabilities state of Ukrainian banks was assessed of over the past five years. Dynamics and composition of assets and liabilities of Ukrainian banks was analyzed. Internal and external factors are identified and their influence on the total size of assets and liabilities of banks is determined; economic-mathematical model of the influence of external and internal factors on the total assets of banks and the economic-mathematical model of the influence of components of assets and liabilities on their size have been developed; it is proved that the models can be used for further analysis and forecasting. Using the statistical package "Data Analysis" Excel, the most influential factors on the total assets was selected, built an economic-mathematical model and determined how exactly selected factors affect the assets; it is proved that the model can be used for further analysis and forecasting; with the help of the statistical program BP-stat was made a forecast of the amount of assets for five years, taking into account the selected factors.

Key words: assets, liabilities, asset and liability management, impact factors.

Постановка проблеми. Управління активами i пасивами банку - це цілеспрямований процес постійного регулювання структури та динаміки активів і пасивів банку, спрямований на забезпечення економічної ефективності банку з позицій оптимізації ризику та забезпечення достатнього рівня ліквідності. На сучасному етапі розвитку банківської системи України одним із пріоритетних завдань є забезпечення стабільного функціонування і розвитку банків та банківської системи загалом. У зв'язку 3 цим проблема ефективного управління активами та пасивами, як одного 3 чинників фінансової стійкості банків, набуває особливого значення.

Огляд останніх джерел досліджень і публікацій. Значний вклад у вирішення даної наукової проблеми внесли вітчизняні та зарубіжні вчені, такі, як: О.А. Кириченко, І.В. Гіленко [1], В.І. Міщенко, С.Г. Арбузов, Ю.В. Колобов [2], О. В. Золотарьова [3], А.В. Сірко [4].

Однак, незважаючи на суттєві наукові результати, отримані вченими, дотепер управління активами та пасивами банку залишається недостатньо розробленим як в теоретичному, так і в практичному аспектах.

Мета статті полягає у проведенні аналізу активів та пасивів банків України та виокремлення факторів впливу на них.

Основний матеріал і результати. Забезпечення стабільного функціонування та фінансової стійкості банків та банківської системи в цілому є одним 3 пріоритетних напрямків на сучасному етапі розвитку банківської системи. Саме тому постає проблема ефективного управління активами та пасивами, що $є$ одним із чинників фінансової стійкості банків. Проте, ефективне управління активами та пасивами банку значною мірою залежить від розуміння їх економічної сутності. Однак, як показали результати досліджень, дотепер немає єдиної точки зору щодо визначення сутності понять «активи 
банку» та «пасиви банку».

За результатами дослідження, можна сказати, що активи банку - це напрями розміщення та використання ресурсів банку для отримання прибутку при раціональному розподілі ризиків по окремих видах операцій та для підтримки ліквідності банку. Пасиви банку - це ресурси банку, які складаються з власних, залучених і запозичених коштів для проведення активних операцій та одержання прибутку.

Сутність активів і пасивів банків обумовлюється їх роллю в економіці як фінансових посередників, що акумулюють тимчасово вільні кошти суб'єктів господарської діяльності і розміщують їх на умовах повернення, строковості й платності у тих суб'єктів господарства, які потребують цього для забезпечення виробничого процесу.

На початок жовтня 2018 р. в Україні функціонував 81 банк, 3 яких 41 банк 3 іноземним капіталом, у тому числі 24 зі 100\% іноземним капіталом [5].

Масове банкрутство банків в Україні в останні роки за умов дотримання деякими 3 них нормативів діяльності банків [5] свідчить про недосконалість діючої практики управління активами та пасивами банку. Цим визначається необхідність більш детального аналізу даної проблеми.

Розглянемо динаміку складу активів банків України (рис.1). Активи складають істотну частину банківських операцій і в діяльності банків мають одне 3 первинних значень, що формують доходи банків.

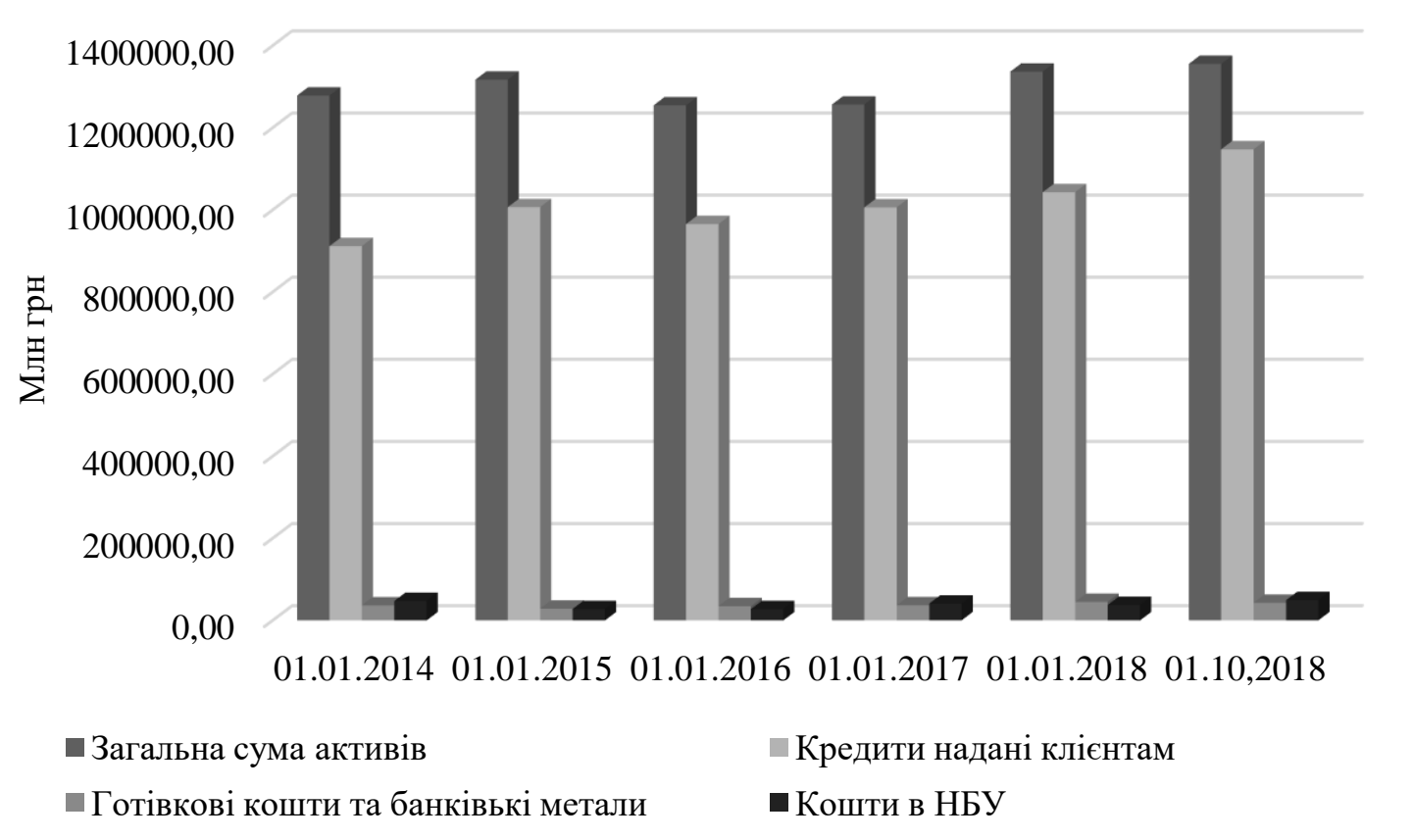

Рисунок 1 - Динаміка складу активів банків України за 01.01.2014 - 01.10.2018 роки [5]

За аналізований період динаміка розмірів активів банків України немає однозначної тенденції щодо збільшення або зменшення: з 2014 р. до початку 2015 р. розмір активів збільшився на 3,03\% (38,8 млрд грн); починаючи з 2015 р. і до початку 2017 р. розмір активів зменшився на 4,6\% (60,6 млрд грн); станом на початок 2018 р. у порівнянні з початком 2017 р. розмір активів банків збільшився на 6,4 \% (80,1 млрд грн); 
на початку жовтня 2018 р. також спостерігалось збільшення розміру активів у порівнянні 3 початком року на 1,41\% (18,8 млрд грн).

Також варто зазначити, що найбільшу питому вагу в структурі активів банку займають кредити надані клієнтам. За аналізований період (з початку 2014 р. до початку жовтня 2018 р.) питома вага кредитів у складі активів коливалась від 71,31\% до 84,65\% відповідно, що є позитивною тенденцією.

Далі розглянемо динаміку складу пасивів банків України (рис. 2).

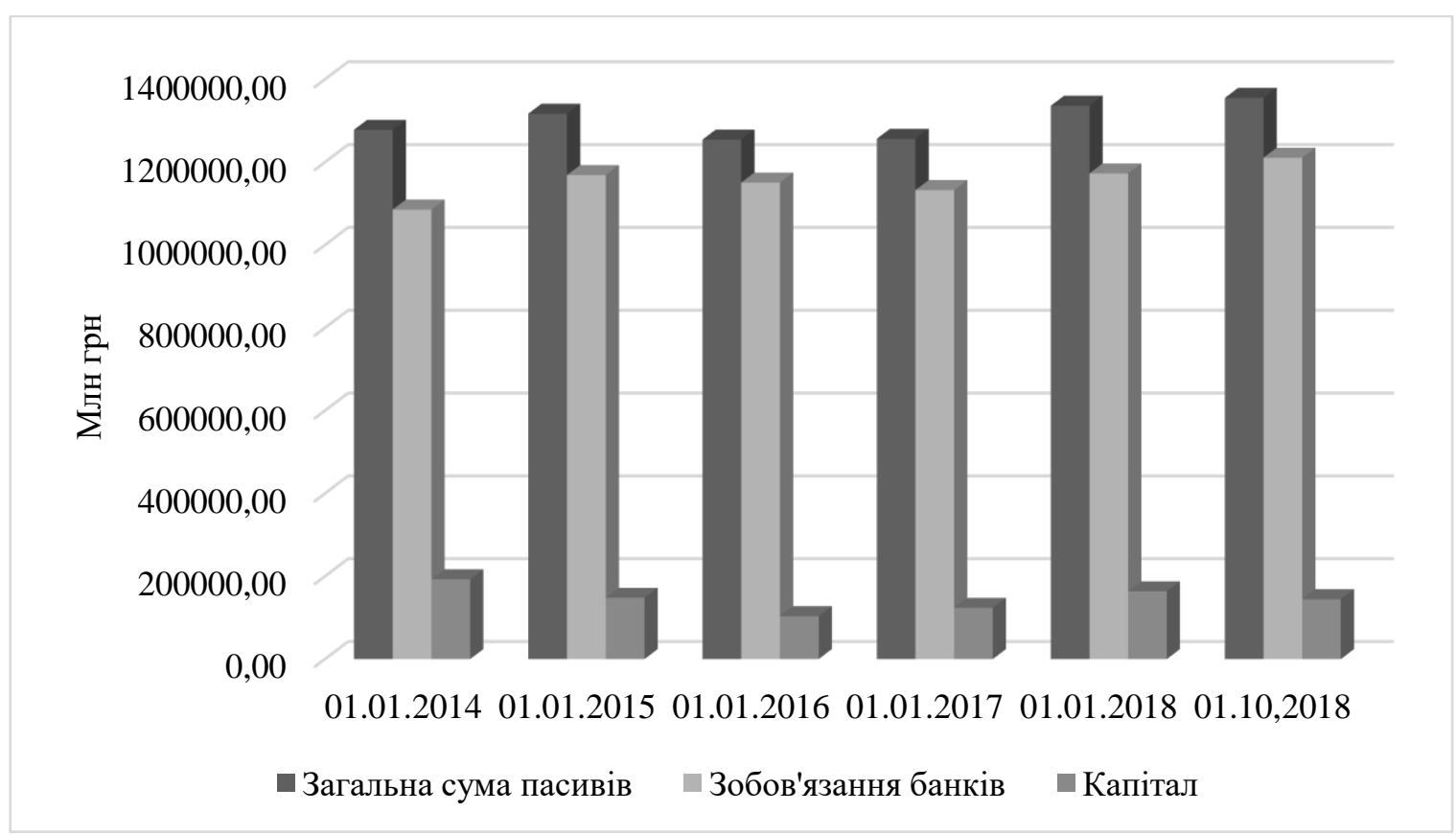
роки [5]

Рисунок 2 - Динаміка складу пасивів банків України за 01.01.2014 - 01.10.2018

Отже, як ми бачимо, зобов'язання банків займають найбільшу питому вагу у складі пасивів банку, за аналізований період (з початку 2014 р. до початку жовтня 2018 р.) дана питома вага коливалась від 84,93\% до 89,33\% відповідно. Розмір зобов'язання банків на початок жовтня 2018 р. у порівнянні з початком 2014 року збільшився на $11,53 \%$ (125 млрд грн), розмір капіталу банку на початок жовтня 2018 р. у порівнянні 3 початком аналізованого періоду зменшився на 24,93\% (48,02 млрд грн).

Також розглянемо динаміку доходів і видатків банків України за 2014-9 місяців 2018 рр. (рис. 3). Проаналізувавши дану динаміку доходів і видатків банків України, ми бачимо, що найбільш збитковим за аналізований період банківський сектор був на початку 2017 року, розмір збитків складав майже 160 млрд грн, що обумовлено резервуванням кредитного портфеля АТ КБ ПриватБанку в кінці 2016 року.

Проте, спостерігається позитивна тенденція зменшення збиткової діяльності банків протягом 2017 р., вже на початку 2018 р. збитки складали 24,4 млрд грн, та станом на початок вересня спостерігалась прибуткова діяльність банків. У першому кварталі 2018 року банки України відновили прибуткову діяльність після збиткової роботи у четвертому кварталі 2017 року. При цьому вони продовжили активно кредитувати населення та залучати депозити фізичних осіб [6]. 


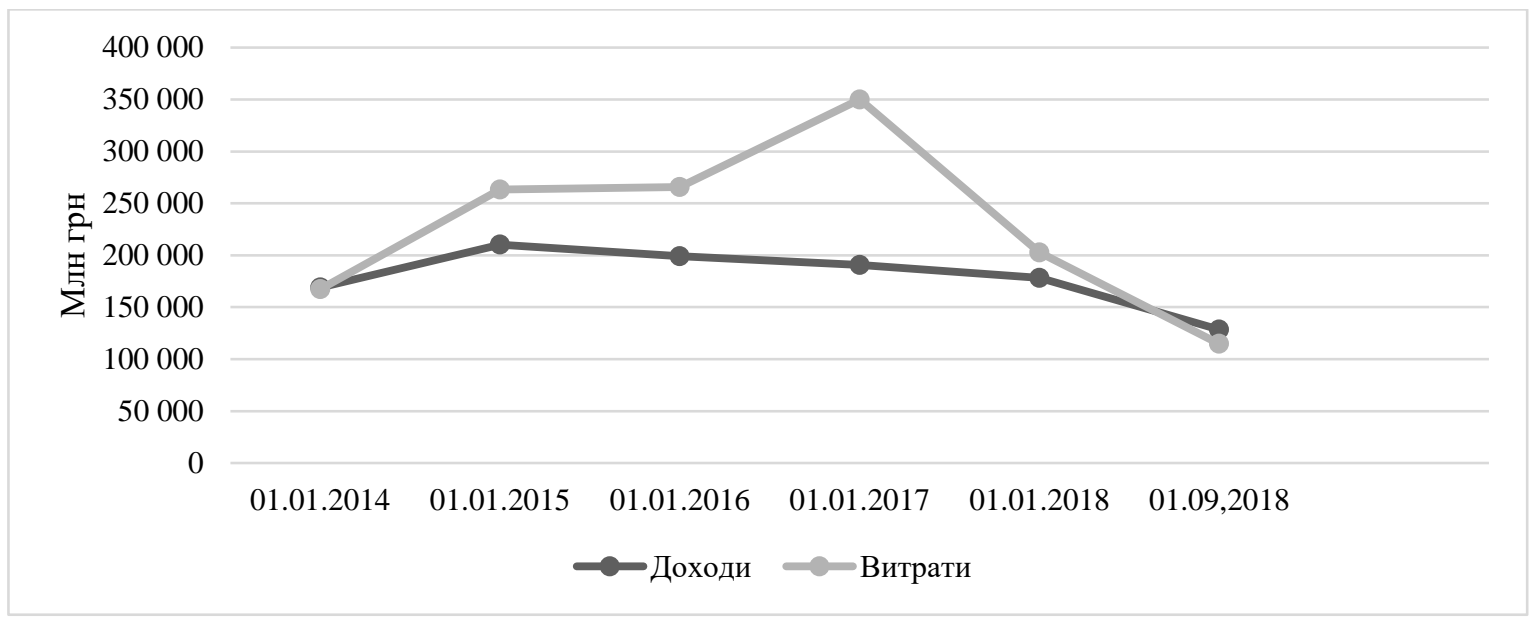

Рисунок 3 - Динаміка доходів і видатків банків України за 2014 - 9 місяців 2018 рp. [5]

На управління активами та пасивами банку безпосередньо впливає видача кредитів та залучення депозитів. Саме тому, розглянемо більш детально структуру виданих кредитів станом на початок 2018 р. у порівнянні з початком 2016 р. (рис. 4).

Таким чином, протягом аналізованого періоду найбільшу питому вагу у складі виданих кредитів займають кредити нефінансовим корпораціям, їх питома вага коливалась від 81,91\% до 82,64\%. У той же час, сума виданих кредитів у гривні збільшилась за аналізований період на 36,00\% (150,52 млрд грн), у доларах - зменшилась на 22,79\% (118,59 млрд грн), в євро - збільшилась на 45,23\% (19,52 млрд грн). Загальна сума виданих кредитів збільшилася на 5,02\% (49,56 млрд грн) [7].

Питома вага виданих кредитів у гривні у загальному складі кредитів від початку 2016 року до початку 2018 року коливалась від 42,37\% до 54,87\%; питома вага кредитів в доларах - від 52,73\% до 39,05\%; питома вага кредитів в євро - від 4,37\% до 6,05\% [7].
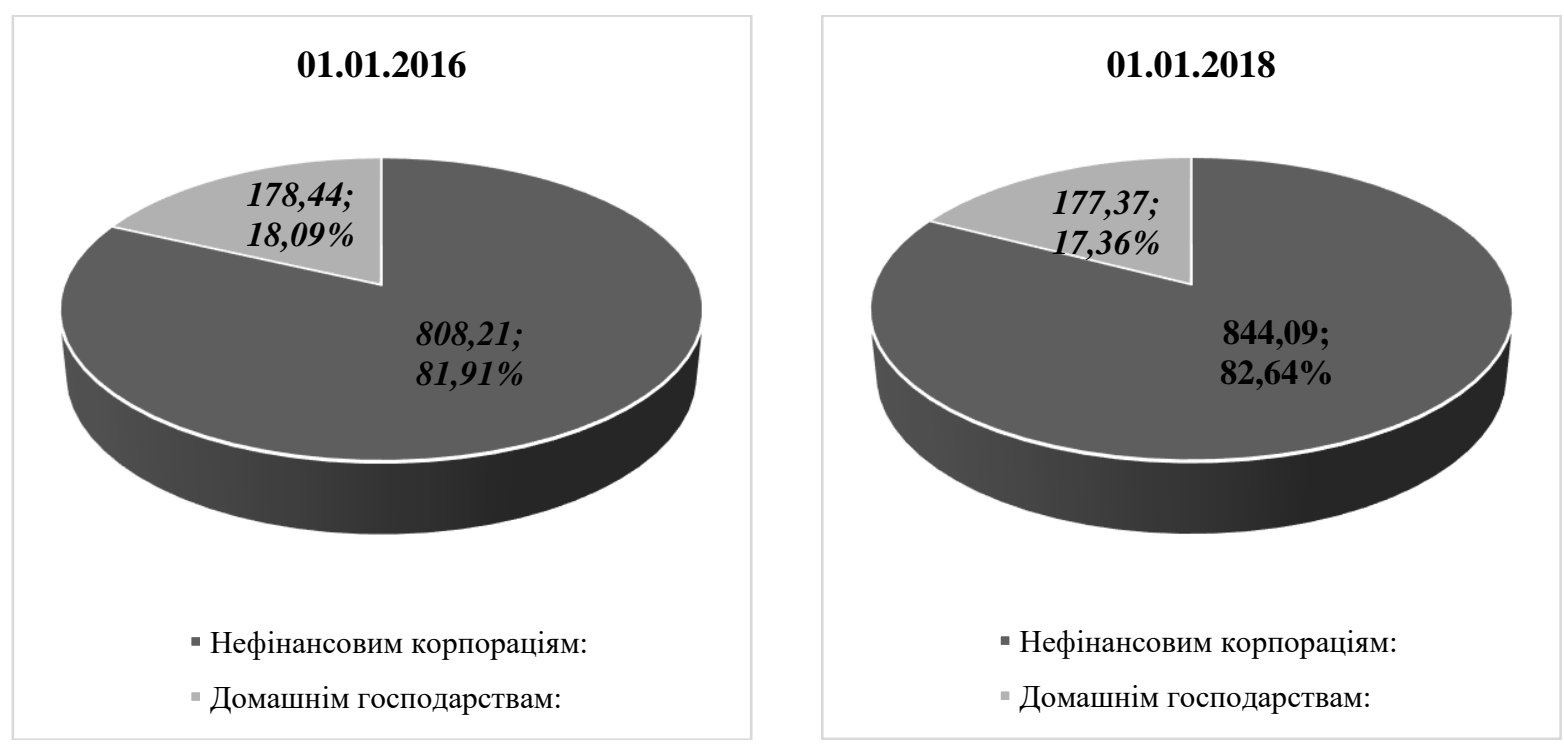

Рисунок 4 - Динаміка та структура обсягу виданих кредитів банками України, млрд грн, \% [7] 
Отже, спостерігається тенденція до зменшення суми виданих кредитів в доларах та збільшення суми виданих кредитів в національній валюті та в євро.

Далі розглянемо більш детально структуру залучених депозитів станом на початок 2018 р. у порівнянні з початком 2016 р. (рис. 5).
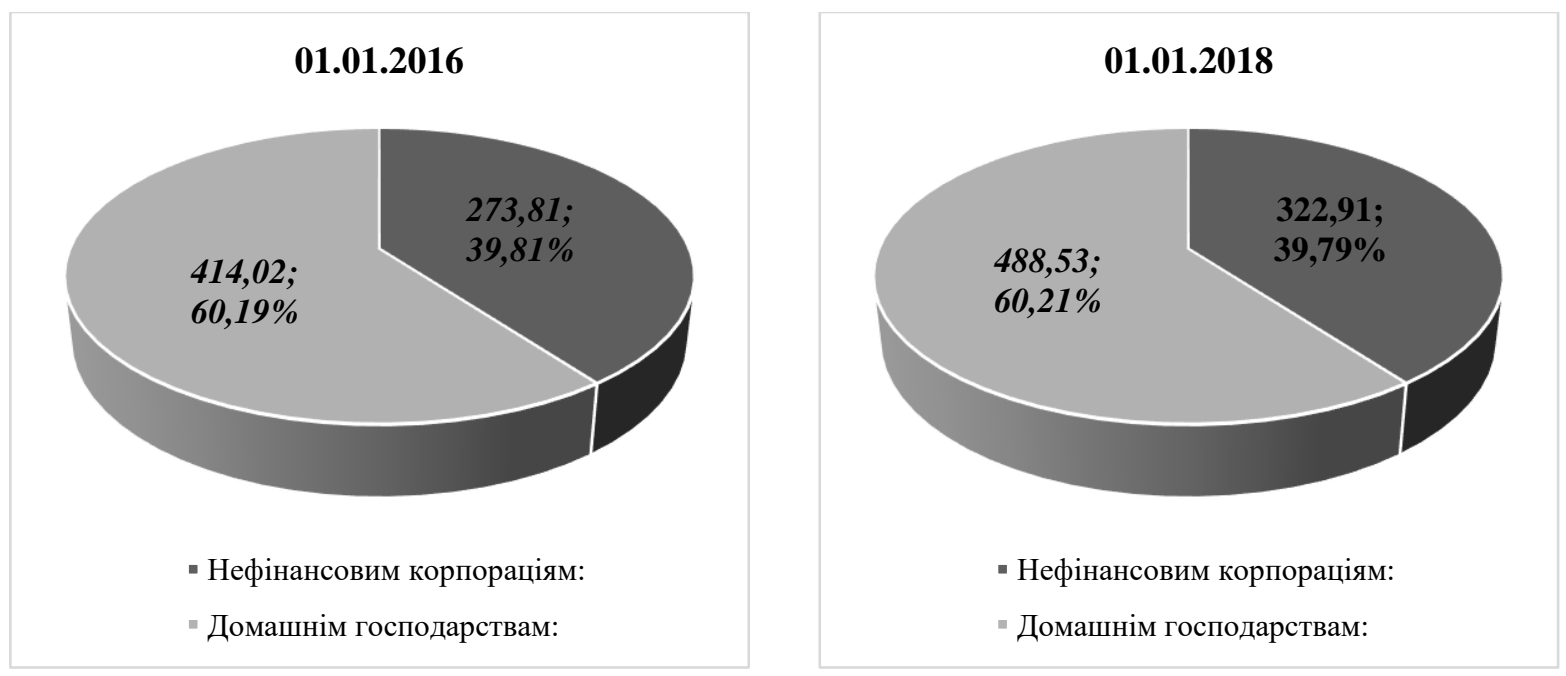

Рисунок 5 - Динаміка та структура обсягу залучених депозитів банками України, млрд грн, \% [7]

Протягом аналізованого періоду найбільшу питому вагу у складі залучених депозитів займають депозити домашніх господарств, їх питома вага коливалась від $60,19 \%$ до 60,21\%. Сума залучених депозитів у гривні збільшилась за аналізований період на 23,63\% (85,7 млрд грн), у доларах - на 10,01\% (27,11 млрд грн), в євро збільшилась на 33,08\% (16,79 млрд грн) [7].

Загальна сума залучених депозитів за аналізований період збільшилась на $18,77 \%$ (129,13 млрд грн). Питома вага залучених депозитів у гривні у загальному складі депозитів від початку 2016 року до початку 2018 року коливалась від 52,73\% до 54,89\%; питома вага депозитів в доларах - від 39,36\% до 36,46\%; питома вага депозитів в євро від 7,38\% до 8,27\% [7]. Як ми бачимо, спостерігається тенденція до зменшення суми залучених депозитів в доларах та збільшення суми залучених депозитів в національній валюті та в євро.

Отже, ефективне управління активами і пасивами банку виступає основою забезпечення його фінансової стійкості; на управління активами та пасивами банку впливають різноманітні фактори, які в свою чергу можна поділити на зовнішні та внутрішні; найбільшу питому вагу в структурі активів банку за аналізований період займають кредити надані клієнтам, у складі пасивів банків України найбільшу питому вагу займають зобов'язання; спостерігається тенденція до зменшення суми виданих кредитів та залучених депозитів в доларах та збільшення суми виданих кредитів в національній валюті та в євро. Тому вважаємо, що доцільно буде визначити вплив зовнішніх та внутрішніх факторів на загальну суму активів та пасивів банків.

До зовнішніх факторів, на нашу думку, можна віднести:

1) загальний стан економіки країни (обсяг доходів та витрат державного бюджету, розмір бюджетного дефіциту, обсяг емісії грошей, грошові доходи населення, 
мінімальна заробітна плата, внески населення в банках, індекс інфляції, облікова ставка НБУ);

2) розвиток банківської системи (рівень капіталізації банків, обсяги сукупних активів, обсяги сукупних зобов'язань банківського сектору, встановлення процентних ставок на банківські продукти та послуги, рівень прибутковості банків тощо);

3) кон'юнктура грошового ринку (депозитна ставка окремих банків, кредитна ставка окремих банків, офіційний курс валют, встановлений НБУ);

4) діяльність контрагентів і конкурентів.

До внутрішніх факторів впливу на управління активами та пасивами банку відносяться:

1) якість фінансового менеджменту (якість управління активами, зобов'язаннями, власним капіталом, рівень ліквідності, рентабельності та платоспроможності);

2) якість організаційного менеджменту (організація систем контролю та безпеки в банку, якість управління персоналом);

3) маркетинг в банку (якість процесу планування в банку, розвиненість відносин 3 клієнтами, спектр послуг і продуктовий ряд банку, якість і вартість банківських продуктів, якість системи просування банківських продукті) [8].

Проаналізуємо більш детально вплив деяких факторів на загальну суму активів та пасивів. Для аналізу візьмемо:

1. зовнішні фактори: доходи державного бюджету, млн грн $\left(\mathrm{X}_{1}\right)$, витрати державного бюджету, млн грн $\left(\mathrm{X}_{2}\right)$, розмір мінімальної заробітної плати, грн $\left(\mathrm{X}_{3}\right)$ та облікова ставка НБУ, \% $\left(\mathrm{X}_{4}\right)$;

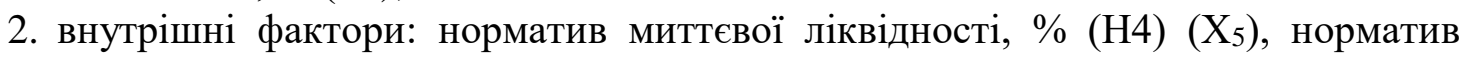
поточної ліквідності, \% (H5) $\left(\mathrm{X}_{6}\right)$, норматив короткострокової ліквідності, \% (H6) $\left(\mathrm{X}_{7}\right)$, рентабельність капіталу, \% $\left(\mathrm{X}_{8}\right)$ (Таблиця 1$)$

Таблиця 1 - Значення відібраних факторів за 2008-2018 pp. [5], [9]

\begin{tabular}{|c|c|c|c|c|c|c|c|c|c|}
\hline Рік & $\begin{array}{c}\text { Y } \\
\text { активи }\end{array}$ & $\mathbf{x 1}$ & $\mathbf{x 2}$ & $\mathbf{x 3}$ & $\mathbf{x 4}$ & $\mathbf{x 5}$ & $\mathbf{x 6}$ & $\mathbf{x 7}$ & $\mathbf{x 8}$ \\
\hline $\mathbf{2 0 0 8}$ & 599396 & 231686 & 241455 & 515 & 10 & 53,6 & 75,31 & 39,93 & 12,67 \\
\hline $\mathbf{2 0 0 9}$ & 926086 & 209700 & 242437 & 625 & 12 & 62,38 & 75,16 & 32,99 & 8,51 \\
\hline $\mathbf{2 0 1 0}$ & 880302 & 240615 & 303589 & 869 & 10,25 & 64,45 & 72,9 & 35,88 & $-32,52$ \\
\hline $\mathbf{2 0 1 1}$ & 942088 & 314617 & 333460 & 941 & 7,75 & 58,8 & 77,33 & 91,19 & $-10,19$ \\
\hline $\mathbf{2 0 1 2}$ & 1054280 & 346054 & 395682 & 1073 & 7,75 & 58,48 & 70,53 & 94,73 & $-5,27$ \\
\hline $\mathbf{2 0 1 3}$ & 1127192 & 339180 & 403403 & 1147 & 7,5 & 69,26 & 79,09 & 90,28 & 3,03 \\
\hline $\mathbf{2 0 1 4}$ & 1278095 & 357084 & 430218 & 1218 & 6,5 & 56,99 & 80,86 & 89,11 & 0,81 \\
\hline $\mathbf{2 0 1 5}$ & 1316852 & 534695 & 576911 & 1218 & 14 & 57,13 & 79,91 & 86,14 & $-30,46$ \\
\hline $\mathbf{2 0 1 6}$ & 1254385 & 616275 & 684743 & 1378 & 22 & 78,73 & 79,98 & 92,87 & $-51,91$ \\
\hline $\mathbf{2 0 1 7}$ & 1256299 & 793265 & 839244 & 3200 & 14 & 60,79 & 102,14 & 92,09 & $-116,7$ \\
\hline $\mathbf{2 0 1 8}$ & 1333831 & 917879 & 991700 & 3723 & 14,5 & 55,55 & 108,08 & 98,37 & $-15,84$ \\
\hline
\end{tabular}

В результаті регресійного аналізу отримуємо рівняння множинної регресії, яке має наступний вигляд:

$$
\begin{gathered}
\mathrm{Y}=-7,95 * \mathrm{X} 1+7,52 * \mathrm{X} 2-202,33 * \mathrm{X} 3+25021,6 * \mathrm{X} 4-13990,67 * \mathrm{X} 5+ \\
17276,1 * \mathrm{X} 6+6479,76 * \mathrm{X} 7-1738,95 * \mathrm{X} 8-174019,67
\end{gathered}
$$


За значенням коефіцієнта детермінації $\mathrm{R}^{2}$ - 0,8887 робимо висновок, що отримане рівняння регресії пояснює коливання результативної ознаки - загальний обсяг активів банку, на $88,87 \%$, решта 11,13\% припадають на фактори, невраховані в моделі. Відносна помилка апроксимації побудованої моделі дорівнює 5,99\%, тобто в середньому розрахункові значення відхиляються від фактичних на 5,99\%. Рівняння можна використовувати в якості регресії, тому що помилка менше $15 \%$.

Таким чином, при збільшенні таких зовнішніх факторів як доходи державного бюджету, розмір мінімальної заробітної плати загальний обсяг активів банків буде зменшуватися, при збільшенні таких зовнішніх факторів як витрати державного бюджету та облікова ставка НБУ - обсяг активів буде зменшуватися.

При збільшенні таких внутрішніх факторів як норматив миттєвої ліквідності та рентабельність капіталу - розмір активів буде збільшуватися; при збільшенні таких внутрішніх факторів як нормативи поточної та короткострокової ліквідності - обсяг активів буде зменшуватися.

Так як при побудові даної моделі виявилось, що 11,13\% припадають на не враховані в моделі фактори доцільно ще проаналізувати вплив складових активів та пасивів на їх загальний обсяг. Для аналізу візьмемо наступні показники: кредити, надані суб єктам господарювання $\left(\mathrm{X}_{1}\right)$; кредити, надані фізичним особам $\left(\mathrm{X}_{2}\right)$; кошти в Національному банку України $\left(\mathrm{X}_{3}\right)$; готівкові кошти та банківські метали $\left(\mathrm{X}_{4}\right)$; зобов'язання банків $\left(\mathrm{X}_{5}\right)$ за 2008-2018 рр.. В результаті регресійного аналізу отримуємо рівняння множинної регресії, яке має наступний вигляд:

$$
Y=-0,392 X_{1}+0,276 X_{2}+2,951 X_{3}+0,843 X_{4}+1,338 X_{5}-103099
$$

Описати отриману модель можна наступним чином:

1) при збільшенні обсягу кредитів, наданих суб`єктам господарювання на 1 млн грн загальний обсяг активів банку зменшиться на 0,392\%;

2) при збільшенні обсягу кредитів, наданих фізичним особам на 1 млн грн збільшиться на $0,276 \%$;

3) при збільшенні обсягу коштів в Національному банку України на 1 млн грн збільшиться на 2,951\%;

4) при збільшенні обсягу готівкових коштів та банківських металів на 1 млн грн - збільшиться на $0,843 \%$; $1,338 \%$.

5) при збільшенні обсягу зобов'язань банків на 1 млн грн - збільшиться на

За значенням коефіцієнта детермінації $\mathrm{R}^{2}$ - 0,9947 робимо висновок, що отримане рівняння регресії пояснює коливання результативної ознаки - загальний обсяг активів банку, на 99,47\%, решта 0,53\% припадають на фактори, невраховані в моделі. Відносна помилка апроксимації побудованої моделі дорівнює 1,41\%, тобто в середньому розрахункові значення відхиляються від фактичних на 1,41\%. Рівняння можна використовувати в якості регресії, тому що помилка менше 15\%. Тобто дану модель можна використовувати для подальшого аналізу та прогнозу.

Для прогнозу обсягу активів банку з урахуванням обраних факторів необхідно спрогнозувати значення самих факторів. Прогнозні значення даних факторів було визначено за допомогою програми BP-stat в якій використовувались наступні методи: метод Брауна, метод Хольта, метод Бокса-Дженкінса та метод ОЛІМП. Проаналізувавши значення помилок апроксимації та значення критерію методу найменших квадратів були обрані наступні методи: 
1) для фактору $\mathrm{X}_{1}$ (кредити, надані суб`єктам господарювання), $\mathrm{X}_{2}$ (кредити, надані фізичним особам), $\mathrm{X}_{3}$ (кошти в Національному банку України), $\mathrm{X}_{4}$ (готівкові кошти та банківські метали) - метод ОЛІМП;

2) для фактору $\mathrm{X}_{5}$ (зобов'язання банків) - метод Бокса-Дженкінса.

Використовуючи прогнозні значення факторів було зроблено прогноз на період 3 2019 по 2023 р. (рис. 6). За даним прогнозом, загальний обсяг активів банків на початок 2023 року буде складати 1571,4 млрд грн, відхилення можуть бути в межах від 1371,4 млрд грн до 1771,4 млрд грн.

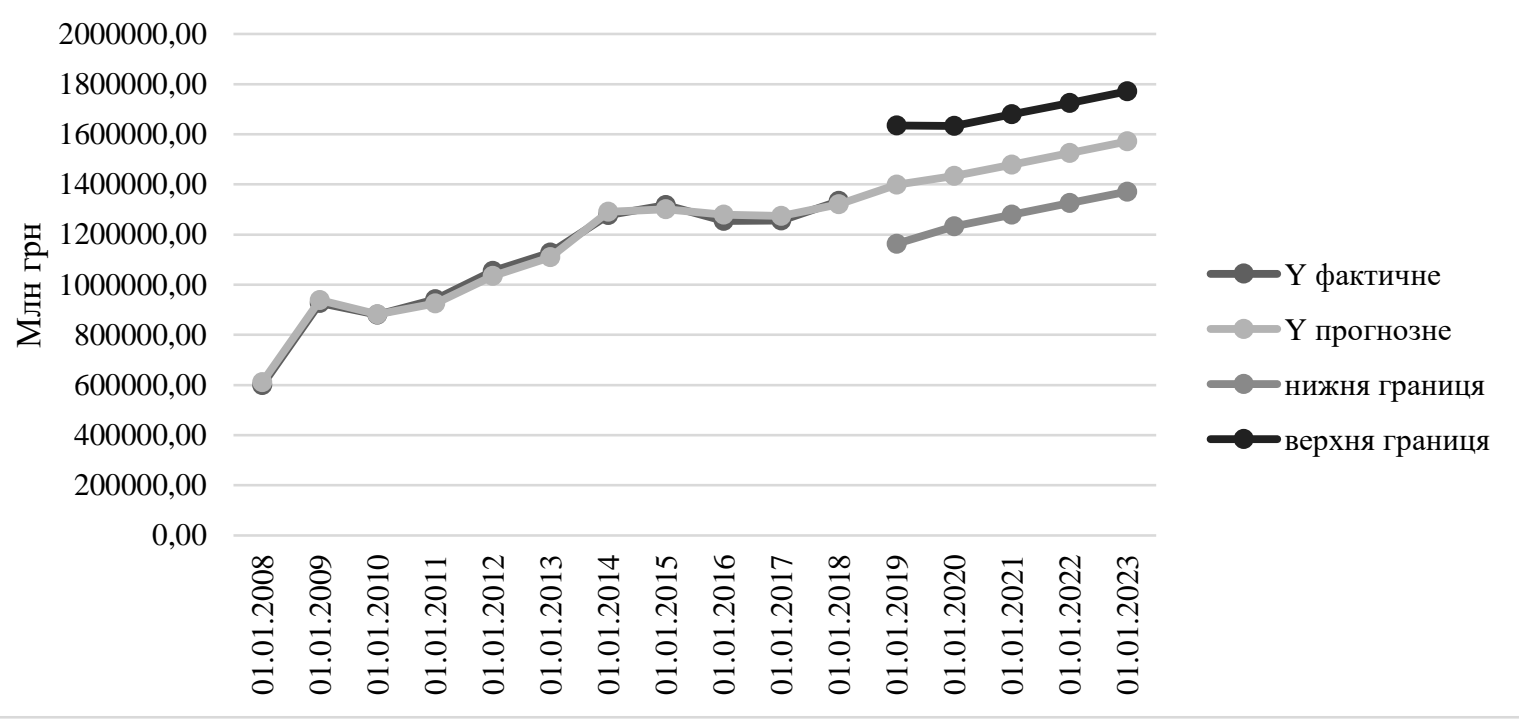
інтервалах

Рисунок 6 - Динаміка обсягу активів банків України і прогнозу в довірчих

Таким чином, можемо сказати, що для ефективного управління активами та пасивами банку необхідно звертати увагу на фактори, як внутрішні так і зовнішні, які мають безпосередній вплив на загальну суму активів та пасивів. Доведено, що зовнішні та внутрішні фактори мають різний вплив на загальний обсяг активів та пасивів банку. Управління активами та пасивами є невід'ємною частиною фінансового менеджменту банку. Як вже зазначалось від ефективності управління активами та пасивами залежить ліквідність банку, спроможність банку функціонувати під впливом різноманітних ризиків, його фінансова стійкість.

Висновки. Нами було визначено, що пасиви банку - це ресурси банку, які складаються з власних, залучених і запозичених коштів для проведення активних операцій та одержання прибутку; активи банку - це напрями розміщення та використання ресурсів банку для отримання прибутку при раціональному розподілі ризиків по окремих видах операцій та для підтримки ліквідності банку. Управління активами та пасивами яке діє наразі в Україні потребує подальшого удосконалення. В результаті макроекономічного аналізу було виділено різноманітні фактори впливу на активи та пасиви банку, які в свою чергу поділяються на внутрішні та зовнішні; в структурі активів банку найбільшу питому вагу за аналізований період займають кредити надані клієнтам, у складі пасивів банків України найбільшу питому вагу займають зобов'язання; спостерігається тенденція до зменшення суми виданих кредитів та залучених депозитів в доларах та збільшення суми виданих кредитів в національній валюті та в євро. Тому, подальше вдосконалення управління активами та пасивами банку рекомендовано здійснювати з урахуванням визначених факторів. 


\section{СПИСОК ВИКОРИСТАНИХ ДЖЕРЕЛ}

1. Кириченко О.А., Гіленко І.В. Поняття активів і пасивів банку. URL: http://www.info-library.com.ua/books-text-2043.html (дата звернення: 25.10.2018)

2. Арбузов С.Г., Колобов Ю.В., Міщенко В.I. Банківська енциклопедія. URL: https://bank.gov.ua/doccatalog/document?id=112997 (дата звернення: 25.10.2018)

3. Золотарьова О.В. Конспект лекцій 3 дисципліни «Банківська система». URL:http://www.dstu.dp.ua/Portal/Data/7/36/7-36-k154.pdf (дата звернення: 29.10.2018)

4. Сірко А.В. Банківська система. Функції та операції банків. URL: http://pidruchniki.com/1314021662933/politekonomiya/bankivska_sistema_funktsiyi_operats iyi_bankiv (дата звернення: 29.10.2018)

5. Основні показники діяльності банків України. URL: https://bank.gov.ua/ control/uk/publish/article?art_id=34661442\&cat_id=34798593 (дата звернення: 30.10.2018)

6. Шварц О.В. Удосконалення інструментарію управління активами і пасивами банку в умовах фінансової нестабільності URL: http://dspace.tneu.edu.ua/bitstream/ 316497/19032/1/\%D0\%A8\%D0\%B2\%D0\%B0\%D1\%80\%D1\%86\%20\%D0\%9E..pdf (дата звернення: 30.10.2018)

7. Грошово-кредитна та фінансова статистика URL: https://bank.gov.ua/control/ uk/publish/category?cat_id=58127 (дата звернення: 01.11.2018)

8. Єпіфанов А.О., Васильєва Т.А., Козьменко С.М. Управління ризиками банків URL: http://shron1.chtyvo.org.ua/Yepifanov_Anatolii/Upravlinnia_ryzykamy_bankiv_Tom _2.pdf (дата звернення: 07.11.2018)

9. МінФін: статистичні дані. URL: https://index.minfin.com.ua/ (дата звернення: 07.11.2018) 